Please reference this paper as:

Houldcroft, L., Haycraft, E., \& Farrow, C. (2014). Peer and friend influences on children's eating. Social development, 23(1), 19-40.

\title{
Peer and friend influences on children's eating
}

\author{
Laura Houldcroft ${ }^{a}$ \\ Emma Haycraft ${ }^{a}$ \\ Claire Farrow ${ }^{a *}$
}

a Loughborough University Centre for Research into Eating Disorders, School of Sport, Exercise and Health Sciences, Loughborough University, Loughborough, Leicestershire LE11 3TU UK

* Address correspondence to: Dr Claire Farrow, Loughborough University Centre for Research into Eating Disorders, School of Sport, Exercise and Health Sciences, Loughborough University, Loughborough, Leicestershire LE11 3TU UK. Email: c.v.farrow@lboro.ac.uk; Tel. +44(0)1509 228487; Fax. +44(0)1509 223940. 


\begin{abstract}
Peers and friends are perceived as important role models for the formation of children's attitudes and behaviours. A wealth of research has aimed to establish the contribution of peers and friends to children's developing eating behaviours and their attitudes towards eating. This review describes and evaluates such research. Experimental research examining peer modelling of food consumption and liking is reviewed, and several individual child factors which are suggested to make children more or less receptive to peer and friend influences are discussed. The influence of children's perceptions of their peers' and friend's eating behaviours upon their own eating practices is also explored. The benefits of future longitudinal research to improve understanding of peer and friend influences on children's eating are emphasised.
\end{abstract}

Key words: friendship; modelling; food preference; consumption. 


\section{Peer and friend influences on children's eating}

\section{Introduction}

Eating in childhood is thought to be influenced by multiple figures, the most significant of these being friends, peers and parents (Birch \& Davison, 2001). A strong body of research has identified the influences of parents, in particular mothers, on children's eating attitudes and behaviours (e.g., Faith, Scanlon, Birch, Francis, \& Sherry, 2004; Scaglioni, Salvioni, \& Galimberti, 2008; Wardle \& Carnell, 2007) as mothers are responsible for the majority of feeding interactions that their young children experience (McHale, Crouter, McGuire, \& Updegraff, 1995). Despite the strong evidence suggesting that parental feeding practices influence children's eating attitudes and behaviours, a recent meta-analysis evaluating the similarities between children's and their parents' diets concluded that more attention should be given to the role of other individuals; specifically peers, and their influence on children's eating (Wang, Beydoun, Li, \& Moreno, 2011).

Peers and friends are a central source of influence on children who attend nursery as well as school-aged children, who spend a substantial amount of time with peers and friends in these settings. As children progress through childhood and their schooling lives, their independence increases and the time they spend interacting with peers and friends becomes greater (Sullivan, 1953) and less supervised by their parents (Gifford-Smith \& Brownell, 2003). Peers and friends play an important role in influencing children's developing attitudes and behaviours as children look to these individuals for advice and they act as a social source of reinforcement for 
children's evolving attitudes and behaviours (Hartup, 1984; Sullivan, 1953), gradually becoming more influential as children progress through childhood and into preadolescence (Rubin, Bukowski, \& Parker, 2006). In children and adolescents, peer modelling and friend influences have been studied in several domains, including: delinquency (Mears, Ploeger \& Warr, 1998); self-efficacy (Weiss, McCullagh, Smith \& Berlant, 1998); and risk-taking behaviours (e.g., smoking, alcohol consumption and drug-use; Hoffman, Sussman, Unger \& Valente, 2006; Musher-Eizenman, Holub \& Arnett, 2003).

Evidence suggests that peers and friends are important role models for children's developing eating behaviours and attitudes to eating (e.g., Birch, 1980; Duncker, 1938; Hendy \& Raudenbush, 2000; Salvy, Coelho, Kieffer, \& Epstein, 2007a; Salvy, Romero, Paluch, \& Epstein, 2007b). This, coupled with the evidence that eating and dieting concerns may present themselves as early as during middle-to-late childhood (Koff \& Rierdan, 1991; Ricciardelli, McCabe, Holt, \& Finemore, 2003; Schur, Sanders, \& Steiner, 2000), has resulted in research which has begun to investigate the influences that peers and friends may contribute towards children's eating.

The purpose of the current review is to synthesise and evaluate the literature relating to peer and friend influences on children's eating. After a discussion of the adopted definitions of 'peers' and 'friends', the experimental literature relating to peer modelling of eating is presented, drawing on social theories of eating and learning. The individual child factors that have been linked to children's susceptibility to peer and friend influences on their eating are then reviewed, highlighting the role of weight, familiarity, gender and age. Research examining the influence that children's 
perceptions of their peers' and friends' eating has on their own eating is then assessed, before conclusions are made and suggestions for future work are provided.

\section{The 'peer or friend' distinction}

It is important to make the distinction between 'friends' and 'peers' as the two are conceived as being conceptually different in terms of the type of relationship each provide (Dunn, 2004). Previous research in the eating domain varies substantially in its application of the labels 'peers' and 'friends'. By definition, 'peers' are said to be "individuals who are similar to the child in age and/or developmental level... who do not share kinship or reside within the same family" (Ladd, 1989, p. 5). Using this description, 'peers' include a wide-range of individuals that a child frequently interacts with, for example, a "friend, acquaintance, classmate and teammate" (Ladd, 1989, p.1). On the other hand, the term 'friend' infers a reciprocated relationship between the child and another individual that both enter into voluntarily (Ladd \& Kochenderfer, 1998), a friendship being "a particular type of experience that takes place between two individuals" (Bukowski \& Hoza, 1989, p.19).

Children spend a substantial amount of time in the company of both friends and peers, predominantly in school. However, the distinction can be problematic when reviewing the literature in the area of child eating as 'peer' and 'friend' are sometimes used interchangeably by authors. It is possible that research using peers compared to friends may actually be considering two distinct groups who have differing relationships with children and who may impose different influences on them (see 
Dunn, 2004, for a detailed account of the value of children's friendships). For the purposes of the present review, articles that use both the terms 'peers' and 'friends' are included, making clear as much as possible how the authors have utilised the terms in their research, and distinguishing between the use of peers known to the child (e.g., someone they have interacted with previously, such as a member of their school class) and unfamiliar peers (e.g., someone similar in developmental level, who they have not had previous interactions with and are not known to the child) (Table 1 contains full details of all the studies reviewed and the authors' use of the terms 'peers' and 'friends').

\section{Social influences on eating}

In their review of the social influences on eating, Herman, Roth and Polivy (2003) highlight three main bodies of literature: social facilitation, modelling and impression management, and attempt to bring together the literature in the three areas, which they suggest have developed in isolation of one another. The 'normative model of eating' (Herman et al. 2003) posits that eating is directed by norms specific to the social situation, notably the eating behaviours of others present, and how important their social approval is deemed to be. Experimental and diary studies of social facilitation suggest that, in general, people eat more when in the presence of others

than when alone (e.g., de Castro, 1990; de Castro, Brewer, Elmore, \& Orozco, 1990; de Castro, 1991; Klesges, Bartsch, Norwood, Kautzman, \& Haugrud, 1984; Patel \& Schlundt, 2001), and this has been shown to be greater when eating in the presence of a spouse or family members (de Castro, 1994). In modelling studies, people eat more when their co-eaters eat more, and less when co-eaters eat less (e.g., Conger, 
Conger, Costanzo, Wright, \& Matter, 1980; Goldman, Herman, \& Polivy, 1991; Roth, Herman, Polivy, \& Pliner, 2001), with recent research using adults suggesting that factors such as the weight of the co-eater (e.g., Hermans, Larsen, Herman, \& Engels, 2008), gender of the co-eater (e.g., Salvy, Jarrin, Paluch, Irfan, \& Pliner, 2007c), familiarity of the co-eater (e.g., Salvy et al., 2007c), the quality of the social interaction between co-eaters (e.g., Hermans, Engels, Larsen, \& Herman, 2009) and, initial hunger rate (e.g., Hermans, Herman, Larsen, \& Engels, 2010), may impact on the modelling effects observed.

Impression management research explains why people eat more or less in the presence of others (Herman et al., 2003), with studies suggesting that people eat less when in the presence of others who they believe are observing or evaluating them, compared to when eating alone (e.g., Roth et al., 2001). Herman et al. (2003) suggest that consumption rates rely on individuals' social comparisons of intake and the social approval they wish to gain from the other individuals present. The normative model of eating thus suggests that the presence of peers and friends may increase or limit eating, dependent on the cues children are given by the social situation, as well as the individual factors of children and their co-eaters. This is noteworthy for the present review, given that some of the research presented utilises peers who are familiar to the target child. Peers who are familiar are suggested to facilitate children's responses in a social situation, whereas unfamiliar peers are thought to stimulate inhibition and wariness (Lewis, Young, Brooks, \& Michelson, 1975). However, some work has used unfamiliar peers who were presented as heroes (e.g., Horne et al., 2004; Lowe, Horne, Tapper, Bowdery \& Egerton, 2004). It is possible that familiar peers may be considered by target children to be desirable 
as friends and, likewise, unfamiliar peers presented in a heroic way may too be idolised, both in such a way that the social approval of such individuals may be exaggerated and this may be reflected in the outcomes of such studies.

A theory that is considered key to the underpinnings of our understanding of the influence of individuals on one another's behaviour is Bandura's (1977) 'social learning theory'. Social learning theory proposes that the majority of human behaviour is learned through the observation of others' behaviour; such behaviours are then modelled, or imitated, and depending on whether they are reinforced (rewarded), or discouraged (punished), behaviours are repeated (Bandura, 1977). According to Bandura, a person is most likely to model the behaviours of an individual who they perceive to be similar to them and with whom they associate most regularly, since repeated exposure to a behaviour allows it to be learned more comprehensively (Bandura, 1977). Likewise to Herman et al. (2003), Bandura (1969, p. 241) suggests that "prestige, power, competence, socio-economic status and expertise" affect modelling behaviours. Taken together, in terms of eating, this suggests that the people children spend a significant amount of time interacting with in an eating environment would be influential modellers of food consumption and liking. Since children spend time with their peers and friends during school lunch and snack times, and possibly in other eating situations outside of school, peers and friends are likely to be influential modellers of children's food intake. It could further be hypothesised that children are more likely to model the eating behaviours of peers or friends who they perceive to be of a higher status and power, as suggested above in work using peers who are portrayed as heroes (Horne et al., 2004; Lowe et al., 2004). 


\section{Peer modelling}

In the 1930's, Duncker (1938) was one of the first to explore the influence of peer models on children in the context of eating. Twenty-two target pre-school children (aged 2-6 years) were paired with an unfamiliar peer who showed preferences for foods that differed to their own preferences (as assessed prior to the experiment). Following their peer's selection of foods, target children's food preferences shifted to match the preferences of the peer. The same effect was observed when children were told a story about the food preferences of a fictional hero; children's preferences for a previously disliked food changed to match the preferences of the hero (Duncker, 1938). More recently, a similarly designed study indicated that young children (aged 2-5 years) displayed a shift in preference for initially non-liked foods following four days of exposure to peer modelling. Seventeen children were grouped with three or four unfamiliar peers who were older than them and who showed high preference for the target child's non-liked food, and following peer modelling during lunch times, target children's consumption and preference of the initially non-liked target food increased (Birch, 1980). Although using small sample sizes, these seminal studies (Birch, 1980; Duncker, 1938) provided the preliminary evidence that exposure to peer modelling can influence young children's food preferences and consumption, inducing them to consume and prefer foods they initially dislike, over foods that they like. Contemporary research focussing on food consumption in late childhood reports similar findings. In a study using peer modelling on a video, Romero, Epstein and Salvy (2009) found that girls' (aged 8-12 years) intake of cookies matched that of a 10 year-old girl they watched in a video (who was seen to 
consume a small or large serving of cookies), highlighting the powerful nature of modelling and children's social comparisons of food intake in dictating their own intake of food.

Experimental work has examined the influence of peer modelling on children's consumption of a novel food, directly comparing negative (e.g., peer making negative comments about the target novel foods) and positive (e.g., peer making positive comments about the target novel foods) modelling (Greenhalgh et al., 2009). Consumption of a novel blue food in 3-4 and 5-7 year old children was found to decrease following exposure to negative modelling from unfamiliar peers, however, despite a trend in the data, consumption following positive peer modelling did not differ significantly between children in receipt of modelling compared to controls (Greenhalgh et al., 2009). By introducing positive peer modelling after negative modelling, the authors reported that the effects of negative modelling were successfully reversed in middle-aged children (5-7 years of age), but not for younger children (3-4 years). The implication of such findings is that negative peer modelling may be more potent and long-standing than positive modelling, particularly for younger children.

\section{Peer modelling and rewards}

Other work has expanded on the notion of peer modelling by utilising a rewardbased intervention alongside peer modelling. With reference to the theories of children's learning and imitation (Bandura, 1977), Horne et al.'s (2004) and Lowe et al.'s (2004) peer models, the 'Food Dudes' (two unfamiliar girls and two unfamiliar 
boys aged 12-13 years) were presented to children ranging in age from early- to latechildhood (from 4-11 years of age) in 6 video episodes. In the videos (presented immediately prior to snack time for younger children (aged 4-7 years), and immediately prior to lunch time for older children (aged 7-11 years), the 'Food Dudes' were shown eating and enjoying fruits and vegetables, and battling with the 'Junk Punks', whose aim was to deprive the world of fruit and vegetables. Children were rewarded (with stickers or pencils, for example) for consuming target fruits and vegetables. Horne et al. (2004) also used letters from the 'Food Dudes', read out to the children by their teacher, and involved parents by providing home packs explaining how to encourage their children's consumption of fruits and vegetables.

After 16 school days of the intervention, children's consumption of fruit and vegetables during snack and lunch times increased (Horne et al., 2004; Lowe et al., 2004), as did liking of the fruits and vegetables (Lowe et al., 2004). At a 4 month follow-up, Horne et al. (2004) reported that fruit and vegetable consumption was less than immediately following the intervention, but significantly higher than at baseline. However, the same results were not found for the control group, who were not exposed to the 'Food Dudes' programme, but were instead repeatedly exposed to specific fruits and vegetables in school time. Conversely, their consumption of target fruits and vegetables after repeated exposure declined from baseline levels (Horne et al., 2004). Lowe et al. (2004) however, did not use a control group and measures were taken only at baseline and immediately following the intervention. Results from the 'Food Dudes' studies therefore suggest that repeated exposure alone is not associated with increased consumption and liking of foods, as suggested by other 
research (Wardle, Herrera, Cooke, \& Gibson, 2003) and rather that modelling and rewards are powerful factors predicting food consumption and likeability in children.

In the child feeding domain, parents' use of rewards to encourage children's food consumption is much debated. According to the 'over justification hypothesis' of selfperception, offering a child a reward for a desired behaviour reduces their likelihood of performing that behaviour as it undervalues it (Lepper, Greene, \& Nisbett, 1973; Nisbett \& Valins, 1971). Some research in the area of child feeding advocates that the use of rewards is counterproductive, resulting in a reduced preference for the target food (e.g., Birch, Birch, Marlin, \& Kramer, 1982; Birch, Marlin, \& Rotter, 1984; Wardle et al., 2003). However, a recent review and experimental evidence by Cooke and colleagues have suggested that rewards can be beneficial in increasing food acceptance, but their success hinges on the outcome measure (intake or liking) and the type of reward (tangible or non-tangible) (Cooke et al. 2011a; Cooke, Chambers, Añez, \& Wardle, 2011b). In a cluster-randomised trial, Cooke et al. (2011a) exposed young children (aged 4-6 years) to disliked vegetables, finding that exposure alone led to a maintained liking of the vegetables, but rewards (both tangible (e.g., a sticker) and non-tangible (e.g., praise)) alongside exposure were necessary to provide increases in food consumption long-term (three months after the intervention). As suggested by the authors, these results imply that when intake or consumption is the outcome measured, the effects of rewards are positive, whereas when liking is measured, results are mixed (Cooke et al., 2011a, 2011b).

The results of the 'Food Dudes' (Horne et al., 2004; Lowe et al., 2004) intervention are difficult to elucidate as being attributable to one factor, as peer modelling and 
rewards were utilised simultaneously (as well as parental modelling in Horne et al., 2004). The 'Food Dudes' studies measured both food consumption (Horne et al., 2004; Lowe et al., 2004) and food liking (Lowe et al., 2004), reporting similar results for consumption and liking following the intervention, however as Lowe et al. (2004) did not use a control group or follow-up, it is unclear whether peer modelling resulted in maintained liking. Recent work by the same research team has employed a similar intervention, but with pre-school children aged 2-4 years (Horne et al., 2011). For a period of 16 days, Horne et al. (2011) exposed children to target fruits and vegetables modelled by video characters and class letters, alongside rewards (stickers and badges) for their consumption. Other fruits and vegetables were also presented, but their consumption was not rewarded. The authors reported large increases in target fruit and vegetable consumption, which also generalised to the non-target foods, although to a lesser extent. After rewards were withdrawn, increases in fruit and vegetable consumption were maintained at a 6 month followup.

While it appears that rewards can be powerful factors in predicting increased food consumption in children, it remains unclear from previous research (Horne et al., 2004; Lowe et al., 2004) whether peers, parents and rewards all had an impact on increasing children's fruit and vegetable consumption, or whether some were more important than others. Horne et al.'s (2011) results with younger children suggest that even after rewards are withdrawn, increases in both target and non-target fruit and vegetable consumption persist. Despite age and other differences in methodology and outcome measures, the experimental research points at the 
influence that peer modelling may exert on children's food consumption and liking of foods, particularly when combined with desirable rewards.

\section{Peer individual differences}

Several individual factors have been suggested to determine the impact of peer and friend influences on children's eating, including weight, gender, age and familiarity (of the peer or friend). Research evaluating the effect of the weight of the peer and target child on children's food consumption has produced mixed results. Two studies found that overweight children in late childhood (8-12 years) paired with overweight unfamiliar peers (Salvy et al., 2007b) or overweight friends (Salvy, Howard, Read, \& Mele, 2009) consumed more food, when compared to overweight/non-overweight matched dyads. Furthermore, overweight children (6-12 years of age) have been found to consume more when alone than when in the presence of an unfamiliar peer (Salvy et al. 2007a) or group of unfamiliar peers (Salvy, Kieffer, \& Epstein, 2008a). In contrast, Salvy et al. (2007a) reported that non-overweight children consumed more when eating with unfamiliar peers than when eating alone. These mixed findings suggest that children's social eating environment, in particular whether they eat alone or are paired with peers or friends, and how important their co-eaters' social approval is deemed to be, can have an important influence on their eating behaviour (Herman et al., 2003), and that the weight of the child and/or co-eater may effect this influence.

The familiarity of the peer to the target child can also be significant, as suggested by studies examining the influence of peers on children's eating. Experimental 
evidence reports that children eating with a familiar peer consume more food than children eating in the presence of an unfamiliar peer (Salvy, Vartanian, Coelho, Jarrin, \& Pliner, 2008b; Salvy et al., 2009). These findings parallel the results of de Castro (1994), who established that for adults, food consumption was greater when eating in the presence of family or friends than in the presence of unfamiliar coeaters, as these individuals social facilitated the intake of food. Furthermore, Salvy et al.'s (2009) study, addressing both the familiarity and weight of the peer co-eater and target child, found that non-overweight children who ate with an overweight unfamiliar child consumed less when compared to eating with a non-overweight unfamiliar peer. Findings such as these emphasise the importance of the weight of children and their peers and the peers' familiarity to the child, in eating situations, adding further to the suggested importance of children's perceptions of the weight of their peers (and themselves) in social eating situations.

It is also possible that there may be gender differences in children's susceptibility to peer influences on eating. In a series of studies that compared the effectiveness of teachers versus peers as food modellers, Hendy and Raudenbush (2000; Study Five) found that when new foods were promoted by unfamiliar peers, preschool girls (4-5 years old) were more likely to accept the new food than were boys of a similar age. However, the small sample size of this study limits its generalisability (6 boys, 8 girls). A questionnaire-based study with a larger sample of 264 preadolescents (aged 9-11-years-old) reported that girls, rather than boys, were more likely to believe that being thin would increase their peer likeability (Oliver \& Thelen, 1996). However, in both boys and girls, the belief that being thin would increase likeability by their peers significantly predicted weight and body concerns. Research has further examined 
the gender of peer co-eater/s, rather than the target child. Familiar female peer models of novel foods have been found to be more effective than familiar male models at increasing acceptance and consumption of novel fruits and vegetables in both male and female children aged 3 to 6 years (Hendy, 2002). However, at a follow-up one month later this effect was not maintained (Hendy, 2002).

Results such as those above are noteworthy, given the evidence that girls in late childhood report higher levels of dissatisfaction, eating concern and dieting behaviours compared to boys of the same age (e.g., Thomas, Ricciardelli, \& Williams, 2000; Wood, Becker, \& Thompson, 1996). Numerous studies addressing peer and friend influences on children's eating have employed a sample consisting only of girls, particularly those utilising a preadolescent age group (from 8 years of age) (e.g., Hutchinson \& Rapee, 2007; Romero et al., 2009; Salvy et al., 2007b). However, several studies using mixed gender samples do not report gender differences in peer influences (e.g., Farrow, Haycraft \& Meyer, 2011; Horne et al., 2004), although these have tended to use samples with a wider age range that incorporate younger children (e.g., Horne et al. (2004) used 5-to-11 year olds and Lowe et al. (2004) studied 4-to-11 year olds). However, Farrow et al. (2011) found no gender differences in friend influences on the eating of preadolescent children, aged 8 to 11 years. The differences in the results obtained could be partly attributed to the different designs, with some studies being experimental and focussing on peers (Horne et al., 2004; Lowe et al., 2004; Romero et al., 2009; Salvy et al., 2007a) and others non-experimental and focussing on friends (Farrow et al., 2011; Hutchinson \& Rapee, 2007). 
A further factor which may potentially be associated with children's susceptibility to peer influences on eating is child age (Table 1 details the ages of all study samples reported in this paper). In experimental studies using early childhood samples (aged 2-6 years), the food choices of the younger children in the samples, rather than the older children, were shown to be more influenced by peers (Birch, 1980; Duncker, 1938). Evidence also suggests that younger children's eating (2-6 years of age) is greater influenced by peers older than themselves (Birch, 1980; Duncker, 1938), even when older peers were mixed with peers of the same age as the target children (Birch, 1980). Greenhalgh et al.'s (2009) finding that negative modelling was not successfully reversed by positive modelling for young children (aged 3-4 years) compared to older children (5-7 years), adds further to this evidence and suggests that modelling may be more persistent and difficult to reverse in children in early childhood. In addition, the results of Horne et al.'s (2011) modelling and rewardsbased intervention with 2-4 year old children, report long-term increases in fruit and vegetable consumption that generalised to other non-target foods. However, experimental research using age groups across middle- and late-childhood does not report associations between peer influences and age (e.g., Horne et al., 2004; Lowe et al., 2004; Romero et al., 2009), implying that age may only be a factor associated with peer influences in younger children. It is possible that during early childhood, individuals may be more susceptible to peer modelling as they, unlike individuals in middle- and late- childhood, are still in the early stages of developing their food preferences.

A further individual difference which may impact on children's susceptibly to influences on their eating is siblings. A longitudinal study with adolescent sibling 
pairs (aged 13-16 years) found that older siblings' emotional and external eating were positively associated with their younger siblings' reports of these behaviours 12 months earlier (De Leeuw et al., 2007). Furthermore, children aged 5-11 years have been found to eat more when in the presence of a sibling, compared to when eating with an unfamiliar peer, or eating alone (Salvy et al., 2008b). Although there has been limited research in this area, these two studies imply that siblings can influence the food consumption of their sibling/s. It is plausible that the number of siblings a child has, the quality of the relationship with siblings, and the age of these siblings, may affect children's susceptibility to peer influences on their eating. A child who interacts daily with siblings at mealtimes may develop a greater resilience to influences on their eating from other people, for example friends and peers. On the other hand, children who do not experience sibling influences during mealtimes may be more susceptible to peer influences on their eating. Further research is needed to understand the mechanisms underlying these influences.

\section{Perceived norms of eating}

Given the evidence which suggests that children are influenced through observational modelling of peers' behaviour (e.g., Birch, 1980; Duncker, 1938; Greenhalgh et al., 2009; Horne et al., 2004; Horne et al., 2011; Lowe et al., 2004), it is also possible that children's perceptions of their peers' and friends' attitudes towards eating may influence their own eating. Social network analysis (Paxton, Schutz, Wertheim, \& Muir, 1999) is a relatively novel practice which researchers have utilised to explore similarities in the eating attitudes and behaviours of friendship groups. The technique involves asking children to name the children they 
are closest to and spend most time with, allowing researchers to establish friendship cliques or social networks. The similarities of attitudes and behaviours within friendship groups can then be explored (Paxton et al., 1999). In research such as this, the focus is on friends, rather than peers who tend to be the focus in experimental designs.

Using social network analysis, adolescent girls have been found to report similar body image concerns, dietary restraint and weight-loss behaviours to girls in their friendship clique (Hutchinson \& Rapee, 2007; Paxton et al., 1999). In a late childhood sample (aged 8-11 years), Farrow et al. (2011) reported similar findings, with children's (both boys' and girls') levels of dietary restraint, body dissatisfaction and external eating being significantly associated with those of other children in their friendship group. Furthermore, friendship group attitudes towards eating did not appear to impact on individual children's eating attitudes directly, but were found to be moderated by the child's own anxiety, with children who were more anxious being more susceptible to peer influences (Farrow et al., 2011). This suggests that children's individual psychopathology may make them more susceptible to friend influences; a link which has also been found with child depression and self-esteem (Hutchinson \& Rapee, 2007). Hutchinson and Rapee (2007) reported that 10-14year-old girls who were members of friendship cliques and regularly dieted or used behaviours to reduce their eating and weight, reported significantly lower selfesteem, higher levels of depression and greater negative emotions. Importantly, to date, experimental investigations into friend and peer modelling have not controlled for children's individual psychopathology (e.g., anxiety, depression and negative emotion) or self-esteem, despite the non-experimental evidence pointing at 
children's psychopathology being linked to their increased susceptibility to peer and friend influences on eating.

Studies not employing social network analysis have reported similar results to those using social network analysis in identifying similarities between children and their friends and peers. For example, a study by Wind et al. (2006) found that perceived modelling of fruit and vegetable consumption by friends (and parents) was positively correlated with children's self-reported intake of fruit and vegetables, for children in late childhood (11 years of age). Oliver and Thelen (1996), when piloting their own measure of peer influences on children's eating (the Inventory of Peer Influence on Eating Concerns; I-PIEC), reported that children's (aged 8-12 years) perceptions of peer influences on their eating, particularly negative peer messages about their body and the belief that peers would like them more if they were thinner, were related to children's own maladaptive eating behaviours and negative eating concerns. Interestingly, Cullen et al. (2001) reported that 9 to 11-year old children's belief that their peers thought that eating fruits and vegetables was good, was negatively associated with children's own reported consumption of these foods, as measured by a questionnaire designed specifically for the study, alongside food diaries. Although all three studies suggest that children's perceptions of their peers' and friends' beliefs about eating have a substantial influence on children's own eating behaviours and attitudes to eating, it is important to note that children's perceptions may not represent the true reality of their peers' and friends' influences. It could be possible that other factors are involved in children's perceptions, for example, child psychopathology (e.g., anxiety, depression and self- 
esteem), and this, along with the different measures utilised, may explain discrepancies in the results found.

Despite the inconsistencies in the measures utilised, research such as that presented above (e.g., Cullen et al., 2001; Farrow et al., 2011; Hutchinson \& Rapee, 2007; Oliver \& Thelen, 1996; Paxton et al., 1999; Wind et al., 2006) suggests that friendship groups and perceptions of peer influences on eating may be associated with children's own eating attitudes and behaviours. However, care must be taken when interpreting such results as they represent cross-sectional studies and therefore only provide data from one time point.

\section{Concluding comments}

Taken together, the articles reviewed here suggest that children possess eating attitudes and behaviours similar to those of their peers and friends, and that modelling of food preferences and consumption by peers can result in an increase in children's consumption and liking of modelled foods; both foods that they already consume regularly as well as novel foods, and can generalise to non-targeted foods. Experimental research such as that by the 'Food Dudes' team (Horne et al., 2004; Horne et al., 2011; Lowe et al., 2004) and the work of Salvy and colleagues (Salvy et al., 2007a; Salvy et al., 2007b; Salvy et al., 2008a; Salvy et al., 2008b; Salvy et al., 2009) has been particularly valuable in drawing attention to the influential roles of peer modelling, rewards, and peer individual factors such as familiarity, weight, gender and age on children's eating. Non-experimental research that has focussed

on children's perceived norms of their peers' and friends' eating has also contributed 
to our understanding in this area, highlighting the role of friendship cliques and groups in influencing children's attitudes to eating and their eating behaviours. Furthermore, some of this work has emphasised the importance of considering child psychopathology when studying the influence peers and friends have on children's eating.

This review highlights the different approaches that experimental and nonexperimental work has adopted in this area. Experimental studies of modelling mostly report using peers who are unknown to the child, such as the 'Food Dudes' or other unfamiliar peers (Birch, 1980; Duncker, 1938; Greenhalgh et al., 2009; Horne et al., 2004; Horne et al., 2011; Lowe et al., 2004; Romero et al., 2009), whereas non-experimental work focuses on the attitudes and behaviours of friends who are known to interact frequently with the child (e.g., Farrow et al., 2011; Hutchinson \& Rapee, 2007; Paxton et al., 1999). For the majority of the experimental work it remains unclear whether these results are maintained outside the research setting longitudinally as studies that include follow-up measurements differ in the length of follow-up time, although have a tendency to be relatively short (with the exception of Horne et al. (2011) whose results were maintained at a 6-month follow-up). Nonexperimental work on children's perceptions of their peers' and friends' eating warrants further exploration to clarify how children process information about peers and, specifically, how their perception of factors relative to their peers and friends (and themselves), such as weight, makes children more or less susceptible to peer influences on their eating. In order to expose the complexity of gender and age differences in the influence of peers and friends on children's eating, more research is required. Longitudinal work, following the same sample of children throughout their 
childhood, would allow for an increased understanding of how peers and friends (together and separately) influence children's eating at different time points and whether this is related to factors individual to the child, such as developmental age, weight and psychopathology. Future research should not overlook the possible role of siblings as a protective, or heightening factor, for friend and peer influences on children's eating behaviours, as the extant literature has to date, ignored this potential contributing factor.

The differing interpretation of the word 'peer' and 'friend' is something that future research should also consider, to allow for a possible distinction between the influence of peers and friends on children's eating. Experimental work that reports pairing children with unfamiliar peers (e.g., Duncker, 1938; Birch, 1980; Greenhalgh et al., 2009) varies in the age and developmental level of the unfamiliar peers used. Furthermore, such social situations with a group of older, unfamiliar peers, are somewhat unnatural to a young child, placing several social demands on them. Experimental work, comparing the role of familiar peers and friends in influencing children's eating, would be of particular benefit as it could potentially provide evidence to suggest peers familiar to the child (e.g. in their school class) and friends should be considered differently when designing interventions aimed at improving children's eating attitudes and behaviours that incorporate these individuals. Such work should also take into account the status of the peers and friends as the social approval children require from these individuals is likely to impact on the influences they project onto children's eating attitudes and behaviours. 
Many studies in this review chose to use only girls, presumably because of the higher incidence of eating disorders in adolescent females compared to males (e.g., Field et al., 2008). Since several studies that included boys and girls did not report gender differences in peer influences (Farrow et al., 2011; Horne et al., 2004; Lowe et al., 2004), neglecting males when researching this area could be an oversight. In addition, other potential moderators and mediators related to peer influence require examination, notably child factors such as temperament, given the evidence which suggests that child psychopathology, in particular, anxiety, depression and selfesteem moderate the relationships between friendship group dietary restraint and children's external eating (Farrow et al., 2011; Hutchinson \& Rapee, 2007). To date, experimental investigations into friend and peer modelling have failed to control for children's individual psychopathology (e.g., anxiety, depression and negative emotion) or self-esteem, nor other potential moderators, such as how many siblings a child has. This is something which future research should consider as there are evidently complex inter-relationships between child and peer or friend factors, influencing eating attitudes and behaviours, which require elucidation.

To our knowledge, this is the first review to address this specific body of literature and it highlights the importance of taking into account the impact of peers and friends when designing interventions aimed at improving children's eating attitudes and behaviours. Given the criticality of the childhood and pre-adolescent periods for the onset of eating and dieting concerns (Davison, Markey, \& Birch, 2003; Kotler, Cohen, Davies, Pine, \& Walsh, 2001), as well as over-eating (Guo, Wu, Chumlea, \& Roche, 2002; WHO, 2012), further research is imperative if we are to better understand the importance of peers and friends in the development of children's 
eating attitudes and behaviours. Unlike parental behaviours in relation to child eating, the behaviours of peers and friends are less easy to modify. If peers and friends are agents of change in childhood, interventions aimed at improving children's eating attitudes and behaviours which take into account the impact of these influential figures are fundamental. 


\section{References}

Bandura, A. (1969). Social-learning theory of identificatory processes. In D. A. Goslin (Ed.), Handbook of socialization theory and research (pp. 213-262). Chicago: Rand McNally.

Bandura, A. (1977). Social learning theory. New Jersey: Prentice-Hall.

Birch, L. L. (1980). Effects of peer models' food choices and eating behaviors on preschoolers' food preferences. Child Development, 51, 489-496.

Birch, L. L., Birch, D., Marlin, D., \& Kramer, L. (1982). Effects of instrumental eating on children's food preferences. Appetite, 3, 125-134.

Birch, L. L., \& Davison, K. K. (2001). Family environmental factors influencing the developing behavioural controls of food intake and childhood overweight. Pediatric Clinics of North America, 48, 893-907.

Birch, L. L., Marlin, D. W., \& Rotter, J. (1984). Eating as the 'means' activity in a contingency: effects on young children's food preferences. Child Development, 55, 431-439.

Bukowski, W. M \& Hoza, B. (1989). Popularity and friendship. Issues in theory, measurement, and outcome. In T. J. Berndt \& G. W. Ladd (Eds.), Peer relationships in child development (pp. 15-45). New York: John Wiley \& Sons.

Conger, J. C., Conger, A. J., Costanzo, P. R., Wright, K. L., \& Matter, J. A. (1980). The effect of social cues on the eating behavior of obese and normal subjects. Journal of Personality, 48, 258-271. 
Cooke, L. J., Chambers, L. C., Añez, E. V., Croker, H. A., Boniface, D., Yeomans, M. R., \& Wardle, J. (2011a). Eating for pleasure or profit: the effect of incentives on children's enjoyment of vegetables. Psychological Science, 22, 190-196.

Cooke, L. J., Chambers, L. C., Añez, E. V., \& Wardle, J. (2011b). Facilitating or undermining? The effect of reward on food acceptance. A narrative review. Appetite, 57, 493-497.

Cullen, K. W., Baranowski, T., Rittenberry, L., Cosart, C., Hebert, D., \& de Moor, C. (2001). Child-reported family and peer influences on fruit, juice and vegetable consumption: reliability and validity of measures. Health Education Research, 16, 187-200.

Davison, K. K., Markey, C. N., \& Birch, L. L. (2003). A longitudinal examination of patterns in girls' weight concerns and body dissatisfaction from ages 5 to 9 years old. International Journal of Eating Disorders, 33, 320-332.

de Castro, J. M. (1990). Social facilitation of duration and size but not rate of the spontaneous meal intake of humans. Physiology and Behavior, 47, 11291135.

de Castro, J. M. (1991). Social facilitation of the spontaneous meal size of humans occurs on both weekdays and weekends. Physiology and Behavior, 49, 12891291.

de Castro, J. M. (1994). Family and friends produce greater social facilitation of food intake than other companions. Physiology and Behavior, 56, 445-455.

de Castro, J. M., Brewer, E. M., Elmore, D. K., \& Orozco, S. (1990). Social facilitation of the spontaneous meal size of humans occurs regardless of time, place, alcohol or snacks. Appetite, 15, 89-101.

de Leeuw, R. N., Snoek, H. M., van Leeuwe, J. F., van Strien, T., \& Engels, R. C. 
(2007). Similarities and reciprocal influences in eating behaviour within sibling pairs: a longitudinal study. Eating Behaviors, 8, 464- 473.

Duncker, K. (1938). Experimental modification of children's food preferences through social suggestion. Journal of Abnormal and Social Psychology, 33, 489-507.

Dunn, J. (2004). Children's friendships. The beginnings of intimacy. Oxford: Blackwell Publishing.

Faith, M. S., Scanlon, K. S., Birch, L. L., Francis, L. A., \& Sherry, B. (2004). Parent-child feeding strategies and their relationships to child eating and weight status. Obesity Research, 12, 1711-1722.

Farrow, C., Haycraft, E., \& Meyer, C. (2011). Similarities between eating attitudes among friendship groups: the moderating role of child anxiety. Journal of Pediatric Psychology, 36, 1144-1152.

Field, A. E., Javaras, K. M., Aneja, P., Kitos, N., Camargo Jr, C. A., Taylor, C. B., \& Laird, N. M. (2008). Family, peer, and media predictors of becoming eating disordered. Archives of Pediatrics \& Adolescent Medicine, 162, 574-579.

Gifford-Smith, M. E., \& Brownell, C. A. (2003). Childhood peer relationships: social acceptance, friendships and peer networks. Journal of School Psychology, 41, 235-284.

Goldman, S. J., Herman, C. P., \& Polivy, J. (1991). Is the effect of a social model on eating attenuated by hunger? Appetite, 17, 129-140.

Greenhalgh, J., Dowey, A.J., Horne, P.J., Lowe, C.F., Griffiths, J. H., \& Whitaker, C.J. (2009). Positive- and negative peer modelling effects on young children's consumption of novel blue foods. Appetite, 52, 646-653.

Guo, S. S., Wu, W., Chumlea, W. C., \& Roche, A. F. (2002). Predicting overweight 
and obesity in adulthood from body mass index values in childhood and adolescence. American Journal of Clinical Nutrition, 76, 653-658.

Hartup, W. W. (1984). The peer context in middle childhood. In W. A. Collins (Ed.), Development during middle childhood: the years from six to twelve (pp. 240282). Washington: National Academic Press.

Hendy, H. M. (2002). Effectiveness of trained peer models to encourage food acceptance in preschool children. Appetite, 39, 217-225.

Hendy, H. M., \& Raudenbush, B. (2000). Effectiveness of teacher modelling to encourage food acceptance in preschool children. Appetite, 34, 61-76.

Herman, C. P., Roth, D. A., \& Polivy, J. (2003). Effects of the presence of others on food intake: a normative interpretation. Psychological Bulletin, 129, 873-886.

Hermans, R. C., Engels, R. C. M. E., Larsen, J. K., \& Herman, C. P. (2009). Modeling of palatable food intake. The influence of quality of social interaction. Appetite, 52, 801-804.

Hermans, R.C., Herman, C. P., Larsen, J. K., \& Engels, R.C. (2010). Social modelling effects on snack intake among young men. The role of hunger. Appetite, 54, 378-383.

Hermans, R.C., Larsen, J.K., Herman, C. P., \& Engels, R. C. (2008). Modeling of palatable food intake in female young adults. Effects of perceived body size. Appetite, 51, 512-518.

Hoffman, B. R., Sussman, S., Unger, J. B., \& Valente, T. W. (2006). Peer influences on adolescent cigarette smoking: a theoretical review of the literature. Substance Use \& Misuse, 41, 103- 155.

Horne, P. J., Greenhalgh, J., Erjavec, M., Lowe, C. F., Viktor, S., \& Whitaker, C. J. 
(2011). Increasing pre-school children's consumption of fruit and vegetables.

A modelling and rewards intervention. Appetite, 56, 375-385.

Horne, P. J., Tapper, K., Lowe, C. F., Hardman, C. A., Jackson, M. C., \& Woolner, J. (2004). Increasing children's fruit and vegetable consumption: a peermodelling and rewards-based intervention. European Journal of Clinical Nutrition, 58, 1649-1660.

Hutchinson, D.M., \& Rapee, R.M. (2007). Do friends share similar body image and eating problems? The role of social networks and peer influences in early adolescence. Behaviour Research and Therapy, 45, 1557-1577.

Klesges, R. C., Bartsch, D., Norwood, J. D., Kautzman, D., \& Haugrud, S. (1984). The effects of selected social variables on the eating behavior of adults in the natural environments. International Journal of Eating Disorders, 3, 35-41.

Koff, E., \& Rierdan, J. (1991). Perceptions of weight and attitudes towards eating in early adolescent girls. Journal of Adolescent Health, 12, 307-312.

Kotler, L. A., Cohen, P., Davies, M., Pine, D. S., \& Walsh, B. T. (2001). Longitudinal relationships between childhood, adolescent, and adult eating disorders. Journal of the American Academy of Child \& Adolescent Psychiatry, 40, 14341440.

Ladd, G. W. (1989). Toward a further understanding of peer relationships and their contributions to child development. In T. J. Berndt and G. W. Ladd (Eds.), Peer relationships in child development (pp. 1-11). New York: John Wiley \& Sons.

Ladd, G. W., \& Kochenderfer, B. J. (1998). Linkages between friendship and 
adjustment during early school transitions. In W. M. Bukowski, A. F. Newcomb and W. W. Hartup (Eds.). The company they keep. Friendship in childhood and adolescence (pp. 322-345). Cambridge: Cambridge University Press.

Lepper, M. R., Greene, D., \& Nisbett, R.E. (1973). Undermining children's intrinsic interest with extrinsic reward: A test of the "overjustification" hypothesis. Journal of Personality and Social Psychology, 28, 129-137.

Lewis, M., Young, C., Brooks, I., \& Michelson, L. (1975). The beginning of friendship. In M. A. Lewis and L. A. Rosenblum (Eds.). Friendship and peer relations (pp. 27-66). New York: Wiley.

Lowe, C. F., Horne, P. J., Tapper, K., Bowdery, M., \& Egerton, C. (2004). Effects of a peer modelling and rewards-based intervention to increase fruit and vegetable consumption on children. European Journal of Clinical Nutrition, 58, 510-522.

McHale, S. M., Crouter, A. C., McGuire, S. A., \& Updegraff, K. A. (1995). Congruence between mothers' and fathers' family relations and children's well being. Child Development, 66, 116-128.

Mears, D. P., Ploeger, M., \& Warr, M. (1998). Explaining the gender gap in delinquency: peer influence and moral evaluations of behaviour. Journal of Research in Crime and Deliquency, 35, 251- 266.

Musher-Eizenman, D. R., Holub, S. C., \& Arnett, M. (2003). Attitude and peer influences on adolescent substance use: the moderating effect of age, sex, and substance. Journal of Drug Education, 33, 1- 23.

Nisbett, R. E., \& Valins, S. (1971). Perceiving the causes of one's own behaviour. New York: General Leaning Press.

Oliver, K.K., \& Thelen, M. H. (1996). Children's perception of peer influence on eating concerns. Behavior Therapy, 27, 25-39. 
Patel, K. A., \& Schlundt, D. G. (2001). Impact of moods and social context on eating behaviour. Appetite, 36, 111-118.

Paxton, S. J., Schutz, H. K., Wertheim, E. H., \& Muir, S. L. (1999). Friendship clique and peer influence on body image concerns, dietary restraint, extreme weight-loss behaviors, and binge eating in adolescent girls. Journal of Abnormal Psychology, 108, 255-266.

Ricciardelli, L. A., McCabe, M. P., Holt, K. E., \& Finemore, J. (2003). A biopsychosocial model for understanding body image and body change strategies among children. Journal of Applied Developmental Psychology, 24, 475-495.

Romero, N. D., Epstein, L. H., \& Salvy, S. J. (2009). Peer modelling influences girls' snack intake. Journal of the American Dietetic Association, 109, 133-136.

Roth, D. A., Herman, C. P., Polivy, J., \& Pliner, P. (2001). Self-presentational conflict in social eating situations: A normative perspective. Appetite, 36, 165-171.

Rubin, K.H., Bukowski, W., \& Parker, J. (2006). Peer interactions, relationships, and groups. In N. Eisenberg (Ed.), Handbook of child psychology (6th edition): Social, emotional, and personality development (pp. 571-645). New York: Wiley.

Salvy, S.J., Coelho, J. S., Kieffer, E., \& Epstein, L.H. (2007a). Effects of social contexts on overweight and normal-weight children's food intake. Physiology \& Behavior, 92, 840-846.

Salvy, S.J., Howard, M., Read, M., \& Mele, E. (2009). The presence of friends increases food intake in youth. The American Journal of Clinical Nutrition, 90, 282-287.

Salvy, S. J., Jarrin, D., Paluch, R., Irfan, N., \& Pliner, P. (2007c). Effects of social 
influence on eating in couples, friends and strangers. Appetite, 49, 92-99.

Salvy, S. J., Kieffer, E., \& Epstein, L. H. (2008a). Effects of social context on overweight and normal-weight children's food selection. Eating Behaviors, 9, 190-196.

Salvy, S.J., Romero, N., Paluch, R., \& Epstein, L.H. (2007b). Peer influence on preadolescent girls' snack intake: effects of weight status. Appetite, 49, 177-182.

Salvy, S.J., Vartanian, L. R., Coelho, J.S., Jarrin, D., \& Pliner, P.P. (2008b).

The role of familiarity on modelling of eating and food consumption in children. Appetite, 50, 514-518.

Scaglioni, S., Salvioni, M., \& Galimberti, C. (2008). Influence of parental attitudes in the development of eating behaviour. British Journal of Nutrition, 99, 22-25.

Schur, E. A., Sanders, M., \& Steiner, H. (2000). Body dissatisfaction and dieting in young children. International Journal of Eating Disorders, 27, 74-82.

Sullivan, H. S. (1953). The interpersonal theory of psychiatry. New York: Norton.

Thomas, K., Ricciardelli, L. A., \& Williams, R. J. (2000). Gender traits and selfconcept as indicators of problem eating and body dissatisfaction among children. Sex Roles, 43, 441-458.

Wang, Y., Beydoun, M. A., Li, J., \& Moreno, L. A. (2011). Do children and their parents eat a similar diet? Resemblance in child and parental dietary intake: systematic review and meta-analysis. Journal of Epidemiology\& Community Health, 65, 177-189.

Wardle, J., \& Carnell, S. (2007). Parental feeding practices and children's weight. Acta Paediatrica, 96, 5-11.

Wardle, J., Herrera, M. L., Cooke, L., \& Gibson, E. L. (2003). Modifying children's 
food preferences: the effects of exposure and reward on acceptance of an unfamiliar vegetable. European Journal of Clinical Nutrition, 57, 341-348.

Weiss, M. R., McCullagh, P., Smith, A. L., \& Berlant, A. R. (1998). Observational learning and the fearful child: influence of peer models on swimming skill performance and psychological responses. Research Quarterly for Exercise \& Sport, 69, 380- 394.

WHO. (2012). http://www.who.int/dietphysicalactivity/childhood/en/index.html. Accessed $15^{\text {th }}$ February 2012.

Wind, M., de Bourdeaudhuij, I., te Velde, S. J., Sandvik, C., Due, P., Klepp, K. I., \& Brug, J. (2006). Correlates of fruit and vegetable consumption among 11year-old belgian-flemish and dutch schoolchildren. Journal of Nutrition, Education and Behavior, 38, 211-221.

Wood, K. C., Becker, J. A., \& Thompson, J. K. (1996). Body image dissatisfaction in preadolescent children. Journal of Applied Developmental Psychology, 17, 85-100.

Table 1. Summary of reviewed studies 
Peer and friend influences on eating

\begin{tabular}{|c|c|c|c|c|c|c|c|}
\hline Author/s & Country & $\begin{array}{l}\text { Peer or } \\
\text { Friend }\end{array}$ & $\begin{array}{l}\text { Agel Sexl } \\
\text { Sample sizel } \\
\text { Weight }\end{array}$ & $\begin{array}{l}\text { Experimental/ } \\
\text { Non- } \\
\text { experimental }\end{array}$ & Methodology & $\begin{array}{l}\text { Key } \\
\text { variables of } \\
\text { interest }\end{array}$ & Key findings \\
\hline Birch (1980) & USA & $\begin{array}{l}\text { Peers- } \\
\text { groups of } \\
\text { unfamiliar, } \\
\text { older peers }\end{array}$ & $\begin{array}{l}2-5 \text { years; } \\
\text { mixed sex; N= } \\
17 ; \text { weight not } \\
\text { measured. }\end{array}$ & Experimental & $\begin{array}{l}\text { Children were grouped with } 3 \text { or } 4 \text { older } \\
\text { peers who had high preferences for the } \\
\text { target child's non-liked food. Children } \\
\text { were exposed to } 4 \text { lunchtimes of peer } \\
\text { modelling on consecutive days. }\end{array}$ & $\begin{array}{l}\text { Food } \\
\text { preference } \\
\text { and } \\
\text { consumption }\end{array}$ & $\begin{array}{l}\text { Children's consumption and preference of } \\
\text { initially non-liked foods increased after } 4 \text { days } \\
\text { of peer modelling. }\end{array}$ \\
\hline $\begin{array}{l}\text { Cullen et al. } \\
(2001)\end{array}$ & USA & $\begin{array}{l}\text { Peers- } \\
\text { familiar }\end{array}$ & $\begin{array}{l}\text { 9-11 years; } \\
\text { mixed sex; } \mathrm{N}= \\
\text { 230; weight not } \\
\text { measured. }\end{array}$ & $\begin{array}{l}\text { Non- } \\
\text { experimental- } \\
\text { questionnaires }\end{array}$ & $\begin{array}{l}\text { Children completed measures of peer } \\
\text { (and family) influences on their fruit and } \\
\text { vegetable consumption, as well as } \\
\text { completing a daily food record form. }\end{array}$ & $\begin{array}{l}\text { Fruit and } \\
\text { vegetable } \\
\text { consumption }\end{array}$ & $\begin{array}{l}\text { Children's perceptions of their peers' beliefs } \\
\text { about consuming fruit and vegetables were } \\
\text { negatively associated with their own fruit and } \\
\text { vegetable consumption (i.e. children believing } \\
\text { that their peers thought eating fruits and } \\
\text { vegetables was a good thing, had lower levels } \\
\text { of fruit and vegetable consumption } \\
\text { themselves). }\end{array}$ \\
\hline $\begin{array}{l}\text { Duncker } \\
\text { (1938) }\end{array}$ & USA & $\begin{array}{l}\text { Peers- } \\
\text { unfamiliar } \\
\text { and fictional } \\
\text { peers }\end{array}$ & $\begin{array}{l}\text { 2-6 years; } \\
\text { mixed sex; N= } \\
\text { 22; weight not } \\
\text { measured. }\end{array}$ & Experimental & $\begin{array}{l}\text { Children's food preferences were } \\
\text { assessed pre-experiment. They were } \\
\text { then paired with a peer who had } \\
\text { different food preferences. The same } \\
\text { method was used by telling children a } \\
\text { story about a fictional hero who had } \\
\text { food preferences that differed to their } \\
\text { oun. }\end{array}$ & $\begin{array}{l}\text { Food } \\
\text { preference }\end{array}$ & $\begin{array}{l}\text { Children's food preferences shifted to match } \\
\text { the preferences of the peer, when the peer was } \\
\text { real or fictional. }\end{array}$ \\
\hline $\begin{array}{l}\text { Farrow, } \\
\text { Haycraft \& } \\
\text { Meyer (2011) }\end{array}$ & UK & $\begin{array}{l}\text { Friends- self- } \\
\text { reported }\end{array}$ & $\begin{array}{l}\text { 8-11 years } \\
(\mathrm{M}=10.47) ; \\
\text { mixed sex; } \\
\mathrm{N}=154 ; \text { weight } \\
\text { self-reported }\end{array}$ & $\begin{array}{l}\text { Non- } \\
\text { experimental- } \\
\text { questionnaires }\end{array}$ & $\begin{array}{l}\text { Children completed measures of their } \\
\text { eating and weight attitudes, body } \\
\text { dissatisfaction and levels of anxiety. } \\
\text { Children reported the names of other } \\
\text { children in their friendship clique and } \\
\text { friendship groups were constructed by } \\
\text { the authors using social network } \\
\text { analysis techniques. }\end{array}$ & $\begin{array}{l}\text { Friend } \\
\text { similarities in } \\
\text { eating } \\
\text { attitudes and } \\
\text { behaviours }\end{array}$ & $\begin{array}{l}\text { Children's dietary restraint, body } \\
\text { dissatisfaction, and external eating were } \\
\text { significantly related to their friendship groups' } \\
\text { dietary restraint. Children's individual levels of } \\
\text { anxiety moderated the relationships between } \\
\text { friendship group dietary restraint and individual } \\
\text { external eating. Group dietary restraint levels } \\
\text { predicted higher levels of external eating in } \\
\text { children with moderate or high anxiety. }\end{array}$ \\
\hline
\end{tabular}


Peer and friend influences on eating

\begin{tabular}{|c|c|c|c|c|c|c|c|}
\hline Authorls & Country & $\begin{array}{l}\text { Peer or } \\
\text { Friend }\end{array}$ & $\begin{array}{l}\text { Age/ Sexl } \\
\text { Sample sizel } \\
\text { Weight }\end{array}$ & $\begin{array}{l}\text { Experimental/ } \\
\text { Non- } \\
\text { experimental }\end{array}$ & Methodology & $\begin{array}{l}\text { Key } \\
\text { variables of } \\
\text { interest }\end{array}$ & Key findings \\
\hline $\begin{array}{l}\text { Greenhalgh } \\
\text { et al. (2009) }\end{array}$ & UK & $\begin{array}{l}\text { Peers- } \\
\text { unfamiliar }\end{array}$ & $\begin{array}{l}\text { 5-7 years } \\
\text { (Study 1; } \\
\mathrm{N}=35) .3-4 \\
\text { years (Study 2; } \\
\mathrm{N}=44 \text { ); mixed } \\
\text { sex; weight not } \\
\text { measured. }\end{array}$ & Experimental & $\begin{array}{l}\text { Target children were assigned to one of } \\
3 \text { groups and presented with a novel } \\
\text { food. Within groups, each child was } \\
\text { given the novel food on four snack } \\
\text { occasions. Group A received positive } \\
\text { modelling of the novel food on the first } \\
\text { and third occasions, but were alone } \\
\text { when receiving the novel food on the } \\
\text { second and fourth occasions. Group B } \\
\text { had negative modelling first, positive } \\
\text { modelling third, and ate alone on the } \\
\text { second and fourth; Group C ate alone } \\
\text { on all four occasions. }\end{array}$ & $\begin{array}{l}\text { Food (novel) } \\
\text { consumption }\end{array}$ & $\begin{array}{l}\text { When negative peer modelling was employed } \\
\text { alongside presentation of a novel food, food } \\
\text { consumption was inhibited. In younger children } \\
\text { (3-4 years), this was difficult to reverse. } \\
\text { Positive peer modelling increased consumption } \\
\text { of a novel food, but required more than one } \\
\text { exposure. }\end{array}$ \\
\hline $\begin{array}{l}\text { Hendy } \\
\text { (2002) }\end{array}$ & USA & $\begin{array}{l}\text { Peers- } \\
\text { familiar } \\
\text { trained to } \\
\text { model novel } \\
\text { foods }\end{array}$ & $\begin{array}{l}3-6 \text { years }(\mathrm{M}= \\
54.8 \text { months); } \\
\text { mixed sex; } \mathrm{N}= \\
22 ; \text { weight not } \\
\text { measured. }\end{array}$ & Experimental & $\begin{array}{l}\text { Children were presented with } 3 \text { novel } \\
\text { foods: } 1 \text { food had no modelling; } 1 \text { was } \\
\text { modelled by a male familiar peer; } 1 \text { was } \\
\text { modelled by a female familiar peer. } \\
\text { Toys were used as rewards for novel } \\
\text { food consumption. } \\
\text { Children were randomly selected to } \\
\text { model the novel foods, and received } \\
\text { training in modelling from their teachers } \\
\text { prior to the intervention. }\end{array}$ & $\begin{array}{l}\text { Food } \\
\text { consumption- } \\
\text { bites of novel } \\
\text { food } \\
\text { consumed at } \\
\text { baseline, } \\
\text { following } \\
\text { modelling, } \\
\text { and } 1 \text { month } \\
\text { later }\end{array}$ & $\begin{array}{l}\text { Children (male and female) were most likely to } \\
\text { increase acceptance of novel foods (increased } \\
\text { from baseline) when modelled by female peers. } \\
\text { At } 1 \text { month follow-up, food acceptance was not } \\
\text { maintained. However, trained peer models } \\
\text { reported maintained acceptance of foods they } \\
\text { modelled to target children. }\end{array}$ \\
\hline $\begin{array}{l}\text { Hendy \& } \\
\text { Raudenbush } \\
\text { (2000; Study } \\
\text { 5) }\end{array}$ & USA & $\begin{array}{l}\text { Peers- } \\
\text { unfamiliar; } \\
\text { alone; } \\
\text { familiar } \\
\text { teachers }\end{array}$ & $\begin{array}{l}\text { 4-5 years; } \\
\text { mixed sex; } \\
\text { N=14; weight } \\
\text { not measured. }\end{array}$ & Experimental & $\begin{array}{l}\text { Children were exposed to one of } 3 \\
\text { conditions: teacher modelling of a new } \\
\text { food; unfamiliar peer modelling of a } \\
\text { new food; exposure only to new food } \\
\text { (no modelling). }\end{array}$ & $\begin{array}{l}\text { Food } \\
\text { 'acceptance' } \\
\text { (bites) of a } \\
\text { new food } \\
\text { immediately, } \\
\text { and at } 1 \\
\text { month }\end{array}$ & $\begin{array}{l}\text { For immediate food acceptance there were no } \\
\text { differences found by condition (unfamiliar peer/ } \\
\text { teacher/ alone). } \\
\text { Girls accepted new foods more when they were } \\
\text { modelled by peers, both immediately and at } \\
\text { follow-up. }\end{array}$ \\
\hline
\end{tabular}


Peer and friend influences on eating

\begin{tabular}{|c|c|c|c|c|c|c|c|}
\hline Author/s & Country & $\begin{array}{l}\text { Peer or } \\
\text { Friend }\end{array}$ & $\begin{array}{l}\text { Agel Sexl } \\
\text { Sample sizel } \\
\text { Weight }\end{array}$ & $\begin{array}{l}\text { Experimental/ } \\
\text { Non- } \\
\text { experimental }\end{array}$ & Methodology & $\begin{array}{l}\text { Key } \\
\text { variables of } \\
\text { interest }\end{array}$ & Key findings \\
\hline $\begin{array}{l}\text { Horne et al. } \\
\text { (2004) }\end{array}$ & UK & $\begin{array}{l}\text { Peers- } \\
\text { unfamiliar, } \\
\text { seen on } \\
\text { video }\end{array}$ & $\begin{array}{l}\text { 5-11 years; } \\
\text { mixed sex; N= } \\
749 ; \text { weight not } \\
\text { measured. }\end{array}$ & $\begin{array}{l}\text { Experimental } \\
\text { (with control } \\
\text { group) }\end{array}$ & $\begin{array}{l}\text { Children watched video tapes of the } \\
\text { 'Food Dudes', heroic peers, who } \\
\text { encouraged the consumption of fruits } \\
\text { and vegetables, for } 16 \text { school days. } \\
\text { Teachers also read out letter from the } \\
\text { 'Food Dudes' to children. Children were } \\
\text { rewarded for consumption of target } \\
\text { fruits and vegetables. After } 16 \text { days, } \\
\text { videos stopped and rewards became } \\
\text { less frequent. } \\
\text { The control group did not take part in } \\
\text { the 'Food Dudes' program, but were } \\
\text { presented with the same target fruits } \\
\text { and vegetables to consume at } \\
\text { lunchtime as the experimental group. }\end{array}$ & $\begin{array}{l}\text { Food } \\
\text { consumption- } \\
\text { measured at } \\
\text { baseline, } \\
\text { intervention } \\
\text { and } 4 \text { months } \\
\text { after } \\
\text { intervention }\end{array}$ & $\begin{array}{l}\text { When compared to a control group, children } \\
\text { who received the intervention consumed } \\
\text { significantly more target fruits and vegetables } \\
\text { at intervention and follow-up than at baseline, } \\
\text { both at school and at home. }\end{array}$ \\
\hline $\begin{array}{l}\text { Horne et al. } \\
\text { (2011) }\end{array}$ & UK & $\begin{array}{l}\text { Peers- } \\
\text { unfamiliar, } \\
\text { seen on } \\
\text { video }\end{array}$ & $\begin{array}{l}24-52 \text { months } \\
(\mathrm{M}=34 \mathrm{~m}) ; \\
\text { mixed sex; } \mathrm{N}= \\
20 \text { ( } 8 \text { boys, } 12 \\
\text { girls); weight } \\
\text { not measured. }\end{array}$ & Experimental & $\begin{array}{l}\text { Children watched video tapes of two } \\
\text { characters, who modelled } 2 \text { target } \\
\text { foods (fruit and vegetable pairs) per } \\
\text { video. For } 16 \text { days of baseline, } \\
\text { children were presented with a different } \\
\text { pair of foods per day, at snack time and } \\
\text { lunchtime. Following this, a } 32 \text { day } \\
\text { intervention period, where children } \\
\text { were rewarded for consumption of } \\
\text { target fruits and vegetables, but not } \\
\text { rewarded for consumption of non-target } \\
\text { foods. Follow-ups of consumption were } \\
\text { conducted at } 6 \text { months following } \\
\text { intervention and after rewards had } \\
\text { ceased. }\end{array}$ & $\begin{array}{l}\text { Food } \\
\text { consumption- } \\
\text { measured at } \\
\text { baseline, } \\
\text { following } \\
\text { intervention, } \\
\text { and } 6 \text { month } \\
\text { follow-up }\end{array}$ & $\begin{array}{l}\text { Target fruit and vegetable consumption } \\
\text { significantly increased following the } \\
\text { intervention. Paired, non-target food } \\
\text { consumption also increased. Increases in } \\
\text { consumption were maintained at } 6 \text { month follow } \\
\text { up. }\end{array}$ \\
\hline
\end{tabular}


Peer and friend influences on eating

\begin{tabular}{|c|c|c|c|c|c|c|c|}
\hline Authorls & Country & $\begin{array}{l}\text { Peer or } \\
\text { Friend }\end{array}$ & $\begin{array}{l}\text { Agel Sexl } \\
\text { Sample sizel } \\
\text { Weight }\end{array}$ & $\begin{array}{l}\text { Experimental/ } \\
\text { Non- } \\
\text { experimental }\end{array}$ & Methodology & $\begin{array}{l}\text { Key } \\
\text { variables of } \\
\text { interest }\end{array}$ & Key findings \\
\hline $\begin{array}{l}\text { Hutchinson \& } \\
\text { Rapee } \\
\text { (2007) }\end{array}$ & Australia & $\begin{array}{l}\text { Friends- self- } \\
\text { reported }\end{array}$ & $\begin{array}{l}\text { 10-14 years } \\
(\mathrm{M}=12.3 \mathrm{y}) \\
\text { girls only; } \\
\mathrm{N}=1094 ; \\
\text { weight } \\
\text { measured but } \\
\text { not used as } \\
\text { inclusion or } \\
\text { exclusion } \\
\text { criteria. }\end{array}$ & $\begin{array}{l}\text { Non- } \\
\text { experimental- } \\
\text { questionnaires }\end{array}$ & $\begin{array}{l}\text { Girls completed measures of body } \\
\text { image concerns, eating behaviours, } \\
\text { weight-loss and binge eating } \\
\text { behaviours. They also completed } \\
\text { measures of their friends' concerns with } \\
\text { eating and dieting and how much their } \\
\text { friends influenced them, as well as a } \\
\text { scale of weight-related teasing from } \\
\text { friends. Girls further completed } \\
\text { measures of self-esteem and } \\
\text { depression. Girls reported the names of } \\
\text { other girls in their friendship clique and } \\
\text { friendship groups were constructed by } \\
\text { the authors using social network } \\
\text { analysis techniques. }\end{array}$ & $\begin{array}{l}\text { Friends' } \\
\text { influences on } \\
\text { girls' eating } \\
\text { attitudes and } \\
\text { behaviours }\end{array}$ & $\begin{array}{l}\text { Friends shared similar scores on measures of } \\
\text { eating, dieting, weight-loss and binge eating, } \\
\text { but not body image. Girls' own dieting and } \\
\text { weight-loss behaviours could be predicted by } \\
\text { her friends' scores. } \\
\text { Friendship group scores for eating, dieting, } \\
\text { weight-loss and binge eating were significantly } \\
\text { associated with friendship group perceptions of } \\
\text { peer influences on eating, actual body mass } \\
\text { index and psychological variables. } \\
\text { Girls' perceptions of their friends' influences on } \\
\text { their eating predicted girls' own dieting, weight- } \\
\text { loss and binge-eating behaviours. }\end{array}$ \\
\hline $\begin{array}{l}\text { Lowe et al. } \\
\text { (2004) }\end{array}$ & UK & $\begin{array}{l}\text { Peers- } \\
\text { unfamiliar, } \\
\text { seen on } \\
\text { video }\end{array}$ & $\begin{array}{l}\text { 4-11 years; } \\
\text { mixed sex; N= } \\
\text { 402; weight not } \\
\text { measured. }\end{array}$ & $\begin{array}{l}\text { Experimental } \\
\text { (with control } \\
\text { group- who did } \\
\text { not take part in } \\
\text { the 'Food } \\
\text { Dudes' } \\
\text { program, but } \\
\text { were presented } \\
\text { with the same } \\
\text { target fruits and } \\
\text { vegetables at } \\
\text { lunchtime). }\end{array}$ & $\begin{array}{l}\text { Children watched video tapes of the } \\
\text { 'Food Dudes', heroic peers who } \\
\text { encouraged the consumption of fruits } \\
\text { and vegetables, for } 16 \text { school days. } \\
\text { Children were rewarded for } \\
\text { consumption of target fruits and } \\
\text { vegetables. After } 16 \text { days, videos } \\
\text { stopped and rewards became less } \\
\text { frequent. For } 5 \text { months following the } \\
\text { video and reward intervention, children } \\
\text { were presented with target fruits and } \\
\text { vegetables at lunchtime. Children aged } \\
5-7 \text { years also received fruit at morning } \\
\text { snack-time. }\end{array}$ & $\begin{array}{l}\text { Food } \\
\text { consumption- } \\
\text { measured at } \\
\text { baseline, } \\
\text { intervention } \\
\text { and } 4 \text { months } \\
\text { after } \\
\text { intervention }\end{array}$ & $\begin{array}{l}\text { Lunchtime consumption of fruits and } \\
\text { vegetables was significantly higher at } \\
\text { intervention and follow-up than baseline for the } \\
\text { experimental group. Similarly, snack-time } \\
\text { consumption was higher at intervention than } \\
\text { baseline. Results for lunchtime consumption in } \\
\text { the experimental condition showed large } \\
\text { increases for children who at baseline } \\
\text { consumed very few fruits and vegetables. }\end{array}$ \\
\hline
\end{tabular}


Peer and friend influences on eating

\begin{tabular}{|c|c|c|c|c|c|c|c|}
\hline Authorls & Country & $\begin{array}{l}\text { Peer or } \\
\text { Friend }\end{array}$ & $\begin{array}{l}\text { Age/ Sexl } \\
\text { Sample sizel } \\
\text { Weight }\end{array}$ & $\begin{array}{l}\text { Experimental/ } \\
\text { Non- } \\
\text { experimental }\end{array}$ & Methodology & $\begin{array}{l}\text { Key } \\
\text { variables of } \\
\text { interest }\end{array}$ & Key findings \\
\hline $\begin{array}{l}\text { Oliver \& } \\
\text { Thelen } \\
\text { (1996) }\end{array}$ & USA & $\begin{array}{l}\text { Peers, } \\
\text { familiar }\end{array}$ & $\begin{array}{l}\text { 8-12 years; } \\
\text { mixed sex; N= } \\
264 ; \text { weight } \\
\text { measured but } \\
\text { not used as } \\
\text { inclusion or } \\
\text { exclusion } \\
\text { criteria. }\end{array}$ & $\begin{array}{l}\text { Non- } \\
\text { experimental- } \\
\text { questionnaires }\end{array}$ & $\begin{array}{l}\text { Children completed questionnaire } \\
\text { measures of: their peers' influence on } \\
\text { their eating and body image; their own } \\
\text { body image and eating attitudes; and } \\
\text { their eating disorder symptomology. }\end{array}$ & $\begin{array}{l}\text { Children's } \\
\text { perceptions } \\
\text { of peer } \\
\text { influence on } \\
\text { their own } \\
\text { eating } \\
\text { attitudes and } \\
\text { concerns }\end{array}$ & $\begin{array}{l}\text { Children's perceptions of the influences their } \\
\text { peers had on their eating were linked with their } \\
\text { own eating and body image concerns. How } \\
\text { much children believed they were liked by their } \\
\text { peers (peer likability) was the strongest } \\
\text { predictor of children's eating-related concerns. } \\
\text { Similarly, children's reports of the negative } \\
\text { messages peers gave them about their bodies } \\
\text { were related to their own eating and body } \\
\text { concerns. }\end{array}$ \\
\hline $\begin{array}{l}\text { Paxton et al. } \\
\text { (1999) }\end{array}$ & Australia & $\begin{array}{l}\text { Friends- self- } \\
\text { reported }\end{array}$ & $\begin{array}{l}\text { Age } \mathrm{M}=15.5 \\
\text { years; girls } \\
\text { only; } \mathrm{N}=523 \\
\text { weight and } \\
\text { height } \\
\text { measured but } \\
\text { not used as } \\
\text { inclusion or } \\
\text { exclusion } \\
\text { criteria }\end{array}$ & $\begin{array}{l}\text { Non- } \\
\text { experimental- } \\
\text { questionnaires }\end{array}$ & $\begin{array}{l}\text { Girls completed measures of eating } \\
\text { behaviours, body image concern and } \\
\text { binge eating. Girls also completed } \\
\text { measures of friend support, friend } \\
\text { influences on their body image and } \\
\text { dieting, pressure from peers to be thin, } \\
\text { media pressure to be thin, and family } \\
\text { support they received. Girls completed } \\
\text { psychological measures of self-esteem, } \\
\text { depression. Girls reported the names } \\
\text { of other children in their friendship } \\
\text { group and friendship cliques were } \\
\text { constructed using social network } \\
\text { analysis techniques. }\end{array}$ & $\begin{array}{l}\text { Friend } \\
\text { similarities in } \\
\text { eating } \\
\text { attitudes and } \\
\text { behaviours, } \\
\text { dieting and } \\
\text { binge eating }\end{array}$ & $\begin{array}{l}\text { Similarities for friends' body image, dietary } \\
\text { restraint and eating and weight loss was } \\
\text { greater within- groups than between-groups. } \\
\text { Friends' attitudes to eating predicted girls' } \\
\text { individual eating and body image. Friends' use } \\
\text { of eating and weight loss behaviours predicted } \\
\text { girls' individual use of such behaviours. }\end{array}$ \\
\hline $\begin{array}{l}\text { Romero, } \\
\text { Epstein \& } \\
\text { Salvy (2009) }\end{array}$ & USA & $\begin{array}{l}\text { Peer- } \\
\text { unfamiliar, } \\
\text { seen on } \\
\text { video }\end{array}$ & $\begin{array}{l}\text { 8-12 years; } \\
\text { girls only; } N= \\
44 ; 22 \\
\text { overweight22 } \\
\text { non-overweight }\end{array}$ & Experimental & $\begin{array}{l}\text { Overweight and non-overweight girls } \\
\text { watched a video model consume a } \\
\text { large or small serving size of cookies, } \\
\text { using a } 2 \text { (weight status) × } 2 \text { (serving } \\
\text { size) factorial design. }\end{array}$ & $\begin{array}{l}\text { Food } \\
\text { consumption }\end{array}$ & $\begin{array}{l}\text { Girls in the large serving size condition } \\
\text { consumed more cookies than those in the small } \\
\text { serving size. Overweight girls consumed more } \\
\text { cookies than non-overweight girls. There was } \\
\text { no interaction of weight status by serving size. }\end{array}$ \\
\hline
\end{tabular}


Peer and friend influences on eating

\begin{tabular}{|c|c|c|c|c|c|c|c|}
\hline Author/s & Country & $\begin{array}{l}\text { Peer or } \\
\text { Friend }\end{array}$ & $\begin{array}{l}\text { Agel Sexl } \\
\text { Sample sizel } \\
\text { Weight }\end{array}$ & $\begin{array}{l}\text { Experimental/ } \\
\text { Non- } \\
\text { experimental }\end{array}$ & Methodology & $\begin{array}{l}\text { Key } \\
\text { variables of } \\
\text { interest }\end{array}$ & Key findings \\
\hline $\begin{array}{l}\text { Salvy et al. } \\
\text { (2007a) }\end{array}$ & $\begin{array}{l}\text { Netherland } \\
\text { s/ USA }\end{array}$ & $\begin{array}{l}\text { Condition 1: } \\
\text { Peers- } \\
\text { unfamiliar } \\
\text { Condition 2: } \\
\text { Alone }\end{array}$ & $\begin{array}{l}6-10 \text { years; } \\
\text { mixed sex; } N= \\
32 ; 15 \text { lean and } \\
17 \text { overweight }\end{array}$ & Experimental & $\begin{array}{l}\text { Following a preload, children were } \\
\text { given free access to consume pizzas, } \\
\text { while playing with a variety of toys and } \\
\text { games, both alone and in groups } \\
\text { (containing } 4 \text { children). A } 2 \times 2 \text { factorial } \\
\text { design with children's weight status } \\
\text { (overweight/ normal weight) as a } \\
\text { between-subjects factor, and social } \\
\text { context (group/ alone as a within- } \\
\text { subjects factor. The order children took } \\
\text { part in the study was counterbalanced. }\end{array}$ & $\begin{array}{l}\text { Food } \\
\text { consumption } \\
\text { following a } \\
\text { preload }\end{array}$ & $\begin{array}{l}\text { Overweight children consumed more when } \\
\text { alone than when in a group. Healthy-weight } \\
\text { children consumed more with others than when } \\
\text { alone. }\end{array}$ \\
\hline $\begin{array}{l}\text { Salvy et al. } \\
\text { (2007b) }\end{array}$ & USA & $\begin{array}{l}\text { Peers- } \\
\text { unfamiliar }\end{array}$ & $\begin{array}{l}\text { 8-12 years; } \\
\text { girls only; } \mathrm{N}= \\
46 \text { ( } 23 \text { lean: } \\
=1<85 \text { th } \mathrm{BMI} \\
\text { percentile and } \\
23 \text { overweight } \\
\text { or at risk for } \\
\text { becoming } \\
\text { overweight: } \\
>85^{\text {th }} \text { BMl } \\
\text { percentile). }\end{array}$ & Experimental & $\begin{array}{l}\text { Children were paired with a peer and } \\
\text { completed a sorting task for } 45 \\
\text { minutes, with free access to snack } \\
\text { foods. A between-groups design was } \\
\text { used, with weight status as the } \\
\text { between-subjects factor. Half of the } \\
\text { sample was paired with weight- } \\
\text { concordant peers (lean+ lean } \\
\text { overweight+ overweight) and half } \\
\text { paired with weight-discordant peers } \\
\text { (lean+ overweight). Dyads were age- } \\
\text { matched. }\end{array}$ & $\begin{array}{l}\text { Food } \\
\text { consumption } \\
\text { (kilocalories) }\end{array}$ & $\begin{array}{l}\text { Overweight-overweight pairings consumed } \\
\text { more kilocalories than overweight-lean dyads. } \\
\text { Lean girls paired with overweight girls ate a } \\
\text { similar amount to lean-lean dyads. Peer intake } \\
\text { significantly predicted the paired girls' } \\
\text { consumption. }\end{array}$ \\
\hline
\end{tabular}


Peer and friend influences on eating

\begin{tabular}{|c|c|c|c|c|c|c|c|}
\hline Author/s & Country & $\begin{array}{l}\text { Peer or } \\
\text { Friend }\end{array}$ & $\begin{array}{l}\text { Age/ Sexl } \\
\text { Sample sizel } \\
\text { Weight }\end{array}$ & $\begin{array}{l}\text { Experimental/ } \\
\text { Non- } \\
\text { experimental }\end{array}$ & Methodology & $\begin{array}{l}\text { Key } \\
\text { variables of } \\
\text { interest }\end{array}$ & Key findings \\
\hline $\begin{array}{l}\text { Salvy et al. } \\
\text { (2008a) }\end{array}$ & USA & $\begin{array}{l}\text { Condition 1: } \\
\text { Peers- } \\
\text { unfamiliar } \\
\text { Condition 2: } \\
\text { Alone }\end{array}$ & $\begin{array}{l}\text { 10-12 years; } \\
\text { mixed sex; } \mathrm{N}= \\
39 \text { ( } 21 \text { healthy } \\
\text { weight: }<=85 \text { th } \\
\text { BMl percentile } \\
\text { and } 18 \\
\text { overweight/risk } \\
\text { for becoming } \\
\text { overweight: } \\
>85^{\text {th }} \mathrm{BMl} \\
\text { percentile). }\end{array}$ & Experimental & $\begin{array}{l}\text { Children had access to nutrient dense } \\
\text { and energy dense snacks and were } \\
\text { given games as alternative to eating. } \\
\text { Children completed the task alone, or in } \\
\text { pairs. A } 2 \times 2 \text { factorial design with } \\
\text { children's weight status (overweight/ } \\
\text { healthy weight) as a between-subjects } \\
\text { factor, and social context (pair/ alone) } \\
\text { as a within-subjects factor. The order } \\
\text { children took part in the study was } \\
\text { counterbalanced. }\end{array}$ & $\begin{array}{l}\text { Food } \\
\text { consumption } \\
\text { and nutrient/ } \\
\text { energy dense } \\
\text { food choice }\end{array}$ & $\begin{array}{l}\text { Overweight children consumed significantly } \\
\text { more when alone than when paired with an } \\
\text { unfamiliar peer. Overweight children also } \\
\text { consumed more alone than did non-overweight } \\
\text { children when alone. Non-overweight } \\
\text { children's consumption did not differ by social } \\
\text { context. } \\
\text { Children's consumption of nutrient-dense } \\
\text { (healthy), but not energy dense (unhealthy), } \\
\text { snacks, was predicted by their peers' } \\
\text { consumption of these snacks. }\end{array}$ \\
\hline $\begin{array}{l}\text { Salvy et al. } \\
\text { (2008b) }\end{array}$ & USA & $\begin{array}{l}\text { Siblings } \\
\text { pairs, } \\
\text { unfamiliar } \\
\text { peer pairs } \\
\text { and alone }\end{array}$ & $\begin{array}{l}\text { 5-11 years (M= } \\
6.8) ; \text { mixed } \\
\text { sex; } \mathrm{N}=44 \text { (16 } \\
\text { paired with a } \\
\text { sibling; } 10 \\
\text { paired with an } \\
\text { unfamiliar peer } \\
\text { and } 18 \text { alone); } \\
\text { all non- } \\
\text { overweight (not } \\
\text { defined) }\end{array}$ & Experimental & $\begin{array}{l}\text { Children had access to a large amount } \\
\text { of cookies and were given a sorting } \\
\text { task to complete. Children were paired } \\
\text { with a sibling, an unfamiliar peer, or } \\
\text { completed the task alone. }\end{array}$ & $\begin{array}{l}\text { Food } \\
\text { consumption }\end{array}$ & $\begin{array}{l}\text { Children paired with siblings consumed more } \\
\text { than children eating with an unfamiliar peer, or } \\
\text { alone. } \\
\text { Children paired with siblings displayed less } \\
\text { matching of food intake than did children paired } \\
\text { with an unfamiliar child/ eating alone. }\end{array}$ \\
\hline
\end{tabular}


Peer and friend influences on eating

\begin{tabular}{|c|c|c|c|c|c|c|c|}
\hline Author/s & Country & $\begin{array}{l}\text { Peer or } \\
\text { Friend }\end{array}$ & $\begin{array}{l}\text { Agel Sexl } \\
\text { Sample sizel } \\
\text { Weight }\end{array}$ & $\begin{array}{l}\text { Experimental/ } \\
\text { Non- } \\
\text { experimental }\end{array}$ & Methodology & $\begin{array}{l}\text { Key } \\
\text { variables of } \\
\text { interest }\end{array}$ & Key findings \\
\hline $\begin{array}{l}\text { Salvy et al. } \\
\text { (2009) }\end{array}$ & USA & $\begin{array}{l}\text { Friends and } \\
\text { unfamiliar } \\
\text { peers }\end{array}$ & $\begin{array}{l}\text { 9- } 15 \text { years } \\
\text { ( } \mathrm{M}=13 \text { years); } \\
\text { mixed sex; } N= \\
65 \text { ( } 42 \text { non- } \\
\text { overweight, } \\
15^{\text {th }}-85^{\text {th }} \mathrm{BMl} \\
\text { percentile and } \\
23 \text { overweight: } \\
>85^{\text {th }} \mathrm{BMl} \\
\text { percentile). }\end{array}$ & Experimental & $\begin{array}{l}\text { Children had access to nutrient dense } \\
\text { and energy dense snacks and were } \\
\text { given games as alternative to eating. } \\
\text { Children were paired with a similar } \\
\text { aged friend or unfamiliar peer. } \\
\text { A } 2 \times 2 \text { factorial design with children's } \\
\text { weight status (overweight/ non- } \\
\text { overweight) as a between-subjects } \\
\text { factor, and friendship (friend/ unfamiliar } \\
\text { peer) as a within-subjects factor. }\end{array}$ & $\begin{array}{l}\text { Food } \\
\text { consumption } \\
\text { and nutrient/ } \\
\text { energy dense } \\
\text { food choice }\end{array}$ & $\begin{array}{l}\text { Children paired with a friend consumed } \\
\text { significantly more than those paired with an } \\
\text { unfamiliar peer (regardless of the target child's } \\
\text { weight status). } \\
\text { Overweight children paired with an overweight } \\
\text { child (friend or unfamiliar peer) consumed more } \\
\text { snacks (energy dense and nutrient dense) than } \\
\text { overweight children paired with a non- } \\
\text { overweight partner. } \\
\text { Overweight-overweight friend pairs consumed } \\
\text { significantly more than children in other } \\
\text { conditions. } \\
\text { Non-overweight children paired with an } \\
\text { overweight unfamiliar peer consumed less } \\
\text { energy than non-overweight children paired } \\
\text { with non-overweight unfamiliar peers. } \\
\text { Non-overweight children paired with friends } \\
\text { consumed more snacks regardless of their } \\
\text { friends' weight status (non-overweight/ } \\
\text { overweight). }\end{array}$ \\
\hline $\begin{array}{l}\text { Wind et al. } \\
\text { (2005) }\end{array}$ & $\begin{array}{l}\text { Belgium } \\
\text { and } \\
\text { Netherland } \\
\mathrm{s}\end{array}$ & Friends & $\begin{array}{l}11 \text { year olds; } \\
\text { mixed sex; N= } \\
2468 ; \text { weight } \\
\text { not measured }\end{array}$ & $\begin{array}{l}\text { Non- } \\
\text { experimental- } \\
\text { questionnaires }\end{array}$ & $\begin{array}{l}\text { Children completed questionnaire } \\
\text { measures specifically designed by the } \\
\text { authors for this study, to measure } \\
\text { children's fruit and vegetable intake. } \\
\text { Questions about modelling of food } \\
\text { intake from friends were also used. }\end{array}$ & $\begin{array}{l}\text { Fruit and } \\
\text { vegetable } \\
\text { consumption }\end{array}$ & $\begin{array}{l}\text { Children who reported greater fruit and } \\
\text { vegetable consumption also reported } \\
\text { perceiving more food modelling behaviours } \\
\text { from their friends, although many other social } \\
\text { and demographic factors were also associated. }\end{array}$ \\
\hline
\end{tabular}


Peer and friend influences on eating 